\title{
Sikkerhed, sprog og ret
}

I denne artikel vil jeg diskutere et problem, som har fyldt ganske meget i tiden efter 9/11. Problemet angår i al sin enkelthed juridisk-politiske reaktioner på trusler mod freden såsom terrorisme. I denne sammenhæng har den italienske filosof Giorgio Agamben både været en ivrig deltager i debatten og selv været genstand for en del polemik - især efter udgivelsen af Undtagelsestilstand (Agamben 2005) og forskellige yderst kritiske artikler som f.eks. "Bodies Without Words: Against the Biopolitical Tattoo" (Agamben 2004a). Agamben's bidrag til diskussionerne har imidlertid ofte karakter af at være meget lidt formidlende, af og til i en grad så læsere uden videre afviser dem eller identificerer dem med letgenkendelige alternativer, som i virkeligheden ligger et stykke fra Agambens position. Således hænder det ofte, at Agamben bliver forvekslet med en art postmoderne Carl Schmitt.

Denne forveksling er naturligvis ikke uden grund. Agamben har mange gange udtrykt tydelig veneration for Weimar-republikkens mest berømte/berygtede jurist. Der er imidlertid lige så gode grunde til at anse Agamben for at være en stærk kritiker af Schmitt, som der kan gives for, at han er en Schmitt-epigon. Et helt centralt sted, hvor Agamben adskiller sig fra Schmitt, er i forhold til sprogets status i spørgsmålene om ret og sikkerhed. Dette er samtidig stedet, hvor jeg vil gribe an i nærværende artikel for igennem en diskussion af Schmitt, Agamben og enkelte andre at nå en filosofisk analyse af den globale juridisk-politiske situation, som den tager sig ud med 9/11 i bakspejlet. Vi begynder med en kort præsentation af Schmitt.

\section{Lovens fundament}

Hele vejen gennem sit forfatterskab holder Schmitt fast i en forestilling om, at loven kun kan etableres ved at blive funderet i politik- 
kens sfære; for at der kan etableres lov, kræves der orden, og for at etablere orden kræves magtanvendelse. I Schmitts tidlige værk findes paradigmet på den politiske magtanvendelse i den suveræne beslutning, der, som de fleste, der kender Schmitt, vil vide, har formlen: "Suveræn er den, der bestemmer over undtagelsen" (Schmitt 1985: 1). Den suveræne magt er i stand til at skabe og opretholde orden og ret, fordi det er den, der i sidste ende har evnen til at tilsidesætte dem ved at beslutte over undtagelsen.

I det senere værk ændres denne forestilling om lovens grundlag til en rumlig metafor. Således argumenterer Schmitt i Nomos der Erde (Schmitt 1974) med en etymologisk pointe for, at nomos (lov) bør forstås i betydningen "nehmen" (tage) og mere specifikt "landnahme" (at tage land i besiddelse). Den oprindelige gestus, som etablerer lov, er den, der tager land i besiddelse. At tegne en streg i sandet, at bygge et hegn, at etablere en forskel mellem indenfor og udenfor, er ifølge Schmitt det, der gør det muligt at have love og håndhæve dem. Loven findes $\mathrm{i}$ det Schmittianske univers altid $i$ et indenfor; den findes kun $i$ et begranset rum. Dermed er det også nødvendigt for den Schmittianske forståelse af lov, at den er stillet $i$ et modsætningsforhold til anarkiet. Lov og orden er for den konservative tænker noget, som man må kæmpe for i et strengt antagonistisk forhold; de må opretholdes i striden mod de forskellige farer, der truer dem, såsom anarki, borgerkrig eller terrorisme.

På trods af at Agamben følger Schmitt i mange betragtninger, så afviser han dennes forestilling om et klart defineret retligt indenfor, som er stillet overfor anarkiets udenfor. Som Agamben læser Schmitts analyser af suveræniteten, er den aldrig bare skaberen af det stabile (politiske) fundament for lov og orden, men derimod også altid det, som bryder med ordenen. Schmitt forestiller sig, at suveræniteten, fordi den netop er suveræn, ikke kan begrænses på nogen måde, og at den derfor er det eneste, som kan etablere en stabil orden $i$ form af en sondring mellem indenfor og udenfor, mellem lov og anarki. Agamben derimod argumenterer for, at lige netop denne forestilling om suverænitet betyder, at den orden, som suveræniteten kan opstille, altid er prekær og ustabil i forhold til den suveræne magt selv.

Både Schmitt og Agamben tager udgangspunkt i suverænitetens paradoks. Det vil sige det forhold, at "suverænen står udenfor 
den juridiske orden og alligevel tilhører den, fordi det er ham, der kan bestemme om forfatningen skal suspenderes in toto" (Agamben 2004b: 15). Forskellen er nu, at det for Schmitt er pointen, at dette paradoks er det, der gør det muligt for suverænen at opretholde lov og orden, hvorimod det ifølge Agamben betyder, at der på bunden af enhver suveræn orden ulmer en paradoksal struktur, som truer med at omstyrte ordenen. Hvor Schmitts ide om suverænitet følger Thomas Hobbes langt hen ad vejen - Leviathan in der Staatslehre des Thomas Hobbes (Schmitt 2008) er et glimrende bevis herfor (se f.eks. Schmitt 2008: 21) - hvilket vil sige, at Schmitt ser suverænitetens første og væsentligste opgave som det at holde krigen ude af samfundet, så er forholdet mere prækært, når vi nærmer os Agamben. Vi så, at Schmitt i Nomos der Erde etablerer en klar forbindelse mellem jord og lov, eller som det også hedder: mellem 'Ortung' (stedsliggørelse) og 'Ordnung' (orden). Hertil skriver Agamben nu:

Forbindelsen mellem stedsliggørelse (Ortung) og orden (Ordnung), som er konstitutiv for "Nomos der Erde", er derfor endnu mere kompleks end Schmitt hævder. Den indeholder i sin kerne en grundlæggende tvetydighed, en ikke-lokaliserbar indistinktionszone eller undtagelse, der i sidste ende nødvendigvis virker imod den som princippet for dens uendelige afbrydelse (Agamben 2004b: 19-20). ${ }^{1}$

Pointen er, at hvor Schmitt argumenterer for, at suveræniteten er det, der formår at etablere forbindelsen mellem jord og lov, så hævder Agamben at selve det, at Schmitt eksplicit forstår suveræniteten som et paradoks, i sig selv er nok til, at denne forbindelse brydes. Dermed siger Agamben ikke, som flere har troet, at der slet ikke findes ret eller orden eller sikkerhed - at de blot er ideologiske konstruktioner - men derimod, som citatet ovenfor gør det klart, at forholdet mellem ret og undtagelse, indenfor og udenfor, er mere komplekst, end det lader til i Schmitts udlægning, hvor der i sidste instans rent faktisk kan etableres et klart og virksomt skel mellem indenfor og udenfor, som Nomos der Erde finder i barokkens Europa (Schmitt 1974: 117).

I barokken lykkedes det de suveræne fyrster at skabe en orden, der for Schmitt at se var enestående al den stund, at den begrænsede krigen, så denne ikke udviklede sig til en regulær udslettelseskrig, men derimod altid kun var krig mellem fjender, der formåede 
at slutte fred med hinanden. Ifølge Schmitt skyldtes denne juridiskpolitiske succes, at de europæiske suveræne stater var i stand til at drage klare og tydelige linjer for, hvor Jus Publicum Europaeum var gældende, og hvor den ikke var det. De såkaldte 'Lines of Amity', som udgjordes af krebsens vendekreds og medianen som løber gennem øen Ferro i Kanarieøerne (Mattingly 1963: 145), satte en klar og tydelig grænse for, hvad der var inden for den europæiske retsorden, og hvad der var uden for denne orden (Schmitt 1974: 57, 67, 147).

For Agamben er denne tro på amity linjens lyksalighed naiv med hensyn til sit grundlag. Den barokke suverænitet, som Schmitt fejrer, var endnu mere paradoksal end Schmitt selv forestillede sig. Derfor handler Agambens projekt i første omgang om at finde det rette begrebslige apparatur til at forstå disse komplekse relationer, som opstår med en suverænitet, der på en gang er sin egen muligheds- og umulighedsbetingelse.

\section{Sprog og krig}

Agambens forhold til sprog er et godt sted at starte, når vi ønsker at forstå, hvad det er for et begrebsligt apparatur, han stiller op for at løse dette problem. Samtidig er det netop på dette sted, at Agambens filosofiske værk er stærkest i forhold til at analysere og forstå vores tids forhold til lov, rettigheder og sikkerhed.

Den franske psykoanalytiker Jacques Lacan fortalte i sit Seminar $V$ en vittighed, som meget fint kan hiælpe os til at illustrere den betydning, som sproget har for vores forståelse af lov og sikkerhed. Vittigheden går som følger: "En masochist og en sadist mødes. Masochisten siger til sadisten: Gør mig ondt! Hvortil sadisten svarer: Nej!" (Lacan 1998: 67). Pointen, som Lacan vil lave med denne lille historie, er, at sadisten og masochisten egentlig ville udgøre det perfekte par, hvis ikke det lige var fordi, de var sproglige væsener. En masochist møder en sadist og egentlig burde nydelsen følge uproblematisk for dem begge, men sproget selv intervenerer. Fordi de kan tale, bevæger mødet sig i en skæv retning.

I sidste ende er der væsentlige forskelle på, hvordan Lacan og Agamben stiller sig i forhold til sprogets betydning. For indeværende giver det dog god mening at benytte Lacans lille morsomhed 
til at forstå Agamben, da de er enige på et afgørende punkt: sprogets fundament er grundlæggende paradoksalt. Sproget bør ifølge dem begge forstås som et system, der er bygget op omkring et blindt punkt. Det er altså hverken den vellykkede reference eller den vellykkede brug, som er sprogets grundlæggende byggesten. Sprog er tværtimod noget, som grundlæggende kun lader sig gøre på trods af, eller endda netop på grund af, en fundamental umulighed.

Selve det at træde indenfor $i$ et sprog medforer en form for interioritet, som ikke kan siges at have et udenfor på den måde, som Schmitt forestillede sig, at den suveræne stat kunne have det. Hvis man først er trådt ind i sproget, så kan man ikke uden videre slippe ud af det igen. Men samtidig har sproget indbygget som sin forudsætning, at der er noget, som ikke er sprog. For at det skal kunne give mening at tale, må der være noget, man taler om, en 'virkelighed', som på en eller anden måde er ikke-sproglig. Men dette 'andet', som ikke er sprog, er noget, som man aldrig for alvor kan nå ud til og berøre uden, at man har sproget med som hjælpemiddel til at forstå det igennem. Set inde fra sprogets sfære kan det forekomme nødvendigt, at der må være noget uden for sproget, men man kan netop aldrig indse noget om dette udenfor, andet end at det er noget, der er medieret gennem sprog.

Vittigheden illustrerer pointen ganske fint. Man kan ikke forestille sig, at masochisten og sadisten kunne rejse et bestemt sted hen, hvor de ville kunne blive frie af den omstændighed, at sadisten altid i det mindste vil være fristet af at svare nej til masochisten. I Schmitts univers for suveræniteten er det derimod lige netop sådan, at man kan rejse et bestemt sted hen, hvor loven ikke længere gælder. Syd for Krebsens vendekreds og vest for Ferro-medianen herskede den barokke suverænitet ikke; her var der evig og uhæmmet krig.

Den agambenske pointe er nu, at retten og suveræniteten bør forstås som fænomener, der enten ganske enkelt er sproglige, eller som i det mindste skal forstås i analogi til sproget. Det vil sige, at det ikke er så let endda, at flytte sig uden for rettens og suverænitetens sfære, som Schmitt synes at have forestillet sig, at man lykkedes med i barokken. Den rene ikke-sproglige virkelighed er en fantasi, man bliver nødt til at stille op, for at det skal give mening, at holde fast $\mathrm{i}$ en sproglig virkelighed; men der er netop tale om en fantasi. 
På samme måde med Schmitts rene uhæmmede krig hvis man betragter den igennem agambenske briller; den er den fantasi, som Schmitts suveræne magt må formuleres i modsætning til for overhovedet at give mening.

Forskellen mellem Schmitts og Agambens formuleringer af det 'andet' - dvs. af det, der er placeret i et radikalt udenfor - kan dermed præciseres: For Schmitt er det 'andet' nødvendigvis en konkret skikkelse. Det kan være et radikalt udenfor i form af den lovløse krig, det rene anarki, eller det kan være en 'anden' i form af en konkret fjende, en anden suveræn stat, som befinder sig inden for samme legale sfære som en selv. Da Frankrig og Spanien lavede en aftale ved Cateau-Cambresis i 1559, som indebar de førnævnte amity linjer, kom man ikke blot til enighed om ikke at være forpligtiget på at overholde kontrakter på den anden side af linjen. Man kom også til enighed om, at konflikter og uoverensstemmelser inden for linjerne skulle behandles under ordnede forhold. Det betød, at man afskaffede tilintetgørelseskrige; hvis Frankrig og Spanien gik i krig i tiden for Jus Publicum Europaeum, så gjorde de det som fjender, der var i stand til at slutte fred (Schmitt 1974: 113).

Dette billede tager sig anderledes ud i Agambens optik. Her er det langt mere usikkert, hvad der kan præciseres som værende udenfor. Såvel regulære fjender som den uhæmmede krig, er mere uklart definerede i Agambens univers end i Schmitts, netop fordi de skal forstås inde fra en sproglig virkelighed, som er struktureret omkring det, han kalder en 'indistinktionszone' - altså en grundlæggende uklar og paradoksal kerne, som hverken sprog eller ret kan tænkes at være frie af.

\section{Konstruktivisme}

At sproget har en rolle at spille i forhold til spørgsmålene om ret, orden og sikkerhed er naturligvis ikke noget nyt. Tværtimod så er det en pointe, som man har forfulgt igen og igen i forskellige konstruktivistiske tilgange til fænomenerne. Eksempelvis er den såkaldte københavnerskole med Ole Wæver i spidsen blevet berømt for at studere sikkerhed gennem det operationelle begreb 'sikkerhedsliggørelse', der skal forstås som den tale-handling, som ligger i at gøre noget bestemt til et sikkerhedsproblem (Buzan, Wrver \& 
de Wilde 1998: 26). I sidste instans er der ifølge sikkerhedsliggørelsesteorien ikke noget endeligt faktum, som afgør, om noget er et sikkerhedsproblem eller ej. I stedet er det, som gør, at noget bliver til et spørgsmål om sikkerhed, forstyrrelse af freden eller sågar terrorisme, at det bliver italesat som et sikkerhedsspørgsmål, som forstyrrelse af freden eller som terrorisme. Teorien om sikkerhedsliggørelse er interessant for indeværende diskussion, fordi den kan danne et modbillede til Agambens teori. I virkeligheden ligger talehandlingsteorien nemlig meget tættere på Schmitt end på Agamben. Derfor kan et kort blik på denne form for konstruktivisme bringe den indeværende diskussion videre.

Et godt eksempel på, hvorledes konstruktivismen fungerer, tager os tilbage til 1980erne. Nærmere bestemt til Indien i 1984. Den 5. juli 1984 blev Indian Airlines' fly nummer IC405 kapret. Den 24. august skete det samme for Indian Airlines' fly nummer IC421. Begge kapringer var imidlertid eksempler på hændelsesforløb, som var ganske anderledes end dem, vi normalt forbinder med terrorisme og flykapringer. Som forløbene bliver beskrevet af øjenvidner, var de først og fremmest udramatiske. I begge tilfælde bestod kaprerne snarere af overmodige teenagere end af trænede krigere; i begge tilfælde var kaprerne meget dårligt bevæbnede eller slet ikke; i begge tilfælde endte kapringerne fredeligt og uden alvorligt tilskadekomne. Og hvad der er nok så væsentligt: I begge tilfælde var kaprerne yderst høflige og tog sig generelt godt af både passagerer og personale om bord på flyene. Således afløste de kabinepersonalet og hjalp til med at dele mad ud til passagererne. På fly nummer IC421 opstod der endda spontan fællessang. En af kaprerne sad og sang for sig selv, og flere af passagererne stemte i (Nandy 1995: 15).

Ashis Nandy, som har beskrevet disse begivenheder i detaljen, gør naturligvis ikke et stort nummer ud af disse "formidlende omstændigheder" for at sige, at en flykapring i 10.000 meters højde er uskadelig, uproblematisk eller ufarlig. Fra vores nutidige standpunkt (efter 9/11) skulle det være klart, at flykapringers destruktive potentiale er af en sådan grad, at de naturligvis bør tages yderst alvorligt, uanset hvor harmløst de udspiller sig. Det ændrer imidlertid ikke ved den pointe, som Nandy fremviser. Nemlig at man selv i en flykapringssituation kan finde en myriade af betydninger, forståel- 
ser, sympatier, muligheder, åbninger og konsekvenser, som peger i alle tænkelige forskellige og ofte modstridende retninger. Om bord på flyene IC405 og IC421 fandt kaprere, passagerer og personale sammen i et fællesskab, som var præget af både frygt, had og vrede, men også af forståelse, samtale og tilgivelse (Nandy 1995: 6).

Denne komplekse ambivalens gik ifølge Nandy tabt med det samme begivenhederne nåede mediernes og politikkens sfærer:

Pressen, og i særdeleshed lederskribenter og politiske analytikere, var allerede i færd med at bygge historien om kapringerne op til at handle om en gruppe veltrænede, skarpt bevæbnede, nådesløse kommandosoldater, der var blevet sluppet fri i Indien af fjendtlige nationer og forrædere, og som benyttede sig af de indiske lufthavnes dårlige sikkerhedsforanstaltninger (Nandy 1995: 7).

Med andre ord: Selv om det, der skete om bord på flyene, var meget lidt entydigt, og snarere pegede i retningen af meget alvorlige drengestreger end af international terrorisme, så var den umiddelbare reaktion blandt medier og politikere at slå den direkte vej til det, som Wæver ville kalde sikkerhedsliggørelse.

Pointen er, at uanset hvor rationelt en stat fungerer, og uanset hvor gode dens sikkerhedsforanstaltninger er, så er den også altid afhængig af, at dens interventioner anses for at være rigtige og relevante. Med andre ord så er den afhængig af, at virkeligheden bliver forstået og tænkt som et sted, hvor staten med rette kan intervenere, før den gør det. Det er her, sikkerhedsliggørelsen kan sættes ind som eksplicit talehandling; en handling som skaber rum for en anden slags handling. Ideen er, at sikkerhedsliggørelse fungerer som en sproglig ensretterbro; alle strømme flyder i samme retning, når sikkerhedsliggørelsen har sat sig igennem. Derefter venter kun oprydningsarbejdet, som staten har politi og militær til at tage sig af.

\section{Endnu en stramning af sprogets skrue}

På trods af, at der er meget at lære såvel fra sikkerhedsliggørelsesteorien, som Ole Wæver har formuleret den, samt fra andre konstruktivistiske studier, såsom Ashis Nandys, så er der alligevel især ét afgørende sted, hvor jeg mener, konstruktivismen er problematisk. Dette er samtidig stedet, hvor vi for alvor får syn for, hvorle- 
des Agambens forhold til sprog, sikkerhed og lov adskiller sig fra Schmitts.

Problemet med en konstruktivisme som Nandys eller Wævers, er ikke, som visse kritikere ville hævde, at den mangler forbindelse til realiteterne. Snarere er problemet, at de i sprogforståelsen ligger lidt for tæt på Schmitt. Det, de er fælles om, er forestillingen om, at når talehandlingen udføres, så udfores den. Hverken hos Schmitt eller hos konstruktivismen finder vi tilstrækkelig med opmærksomhed på det forhold, at der kunne være en problematisk vej fra start til slut $\mathrm{i}$ en talehandling. Dette kan måske virke som en besynderlig ting at overveje. Når man for eksempel siger ja til præsten i den bestemte situation, som udgør et vielsesritual, så bliver man rent faktisk gift. På samme måde fungerer sproget i mange sammenhænge som et klart defineret middel til et klart defineret mål. Men det, som vi kan lære af Agamben, er lige præcis, at det langt fra er sikkert, at sproget altid fungerer så gnidningsfrit. Snarere må vi anse det for kun at være i ganske særlige stramt orkestrerede situationer, at sproget kan siges at fungere så glat. Ja, der er endda institutioner og praksisser, som er dybt afhængige af, at sprogets virken netop ikke er alt for uproblematisk.

Det, som konstruktivisterne og Schmitt kan siges at være enige om, er med andre ord en bestemt form for instrumentalisme. Begge steder finder vi en implicit accept af forestillingen om, at sproget virker som et middel til at nå et mål. Hos Schmitt finder vi eksempelvis dette middel i konkrete juridiske handlinger. Da de franske og spanske forhandlere indgik en fredsaftale ved Cateau-Cambresis i 1559, som formaliserede betydningen af amity linjerne, skete der rent faktisk noget afgørende (Mattingly 1963: 145); en talehandling lykkedes. Der blev indgået aftaler, og fordi de var tænkt med tilstrækkelig politisk og juridisk dygtighed og fremsynethed, blev disse aftaler bestemmende for de følgende århundreders politiske verden. Således blev sproget anvendt som middel til et mål.

På samme måde fungerer sikkerhedsliggørelse som en talehandling, der er et middel til et mål. I konfrontationen med en virkelighed, som er kompleks og svær at tyde, fyldt med ambivalente interesser og usikkerhed, siger teorien om sikkerhedsliggørelse, at denne særlige talehandling kan virke som det værktøj, der ensretter og deler virkeligheden op i letforståelige modsætninger: dem-os, 
ven-fjende, indenfor-udenfor.

Det er klart, at talehandlingsteorien hverken er eller behøver at være blind for, at der kan ligge hindringer i vejen for sikkerhedsliggørelsen. (Der kan eksempelvis være andre diskurser, som danner konkurrerende verdensbilleder.) Det centrale er dog stadig, at denne tilgang ser på sproget som noget, der, uanset om det virker efter hensigten, altid virker ved at blive brugt aktivt som et instrument eller et værktøj. Og det er her, vi bør være skeptiske. Den fejl, som instrumentalismen gemmer på, er at finde i selve antagelsen om, at sproget i sidste instans fungerer som et middel til et mål.

Vi har allerede set et eksempel på en sprogbrug, som ikke gør andet end at forvirre og forskyde de klart definerede forskelle; i Lacans vittighed med sadisten og masochisten, er det jo netop sproget, der gør, at forholdet mellem dem forstyrres. Sproget bliver dermed netop til det modsatte af et middel til at mål. Sproget er det, der kommer i vejen for, at målet kan nås.

I Herskabet og herligheden [Org. Il Regno e la Gloria] (Agamben 2010) viser Agamben os en anden vej til forståelsen af forholdet mellem sprog og magt. Agambens teori ender et andet sted end Lacans, men de er fælles om udgangspunktet, der udgøres af en dyb skepsis overfor forestillinger om sprog, der enten eksplicit eller implicit accepterer forestillingen om, at sprog grundlæggende er et instrument - et middel til et mål. Lacans interesse er forskydninger, fortalelser og lignende fænomener, hvor vejen fra middel til mål på en eller anden måde går skævt. Agambens interesse er derimod sproget som inaktivitet, det vil sige det sted, hvor midlet holder op med at være 'til et mål' og i stedet blot virker fladt og dødt, som en dyne man slår i.

Projektet i Herskabet og herligheden kan kort beskrives som en udforskning af teologien i tidlig og middelalderlig kristendom ud fra antagelsen om, at de udførlige beskrivelser af den guddommelige orden omkring forholdet mellem Gud som skaber og Gud som frelser, mellem Fader og Søn, og mellem forskellige skarer af engle, kan ses som begrebslige og tankemæssige ophav til senere moderne statsdannelser og strukturer. De betragtninger omkring arbejdsdelingen mellem Fader, Søn og Ånd eller om englenes funktion i det himmelske magtapparatur, som for et moderne øre uvægerligt lyder som abstrakte skolastiske øvelser, bør ifølge Agamben læses, med 
blik for den struktur de optegner over, hvorledes en (guddommelig) regering nødvendigvis må forholde sig til en historisk begrænset og rumligt udstrakt verden.

Selv om teologer som Thomas Aquinas ikke alvorligt diskuterede hvor mange engle, der kunne danse på et knappenålshoved (Parker 2009: 1287), så diskuterede man f.eks. indgående, hvor mange engle af samme type der findes (Aquinas 1964: Q52, A2). Agambens pointe er heroverfor, at dette på ingen måde skal læses som tørre og tåbelige skolastiske øvelser; tværtimod så er der tale om traktater, der udgjorde afgørende ekspositioner af, hvad magt overhovedet er, og af hvordan den forvaltes. Man behøver blot at oversætte det sakrale ord "engel" til det tilsvarende sekulære "bureaukrat" for at gøre sig en idé om den reelle politisk-teoretiske betudning af disse skolastiske øvelser (Agamben 2010: 189). Det helt centrale begreb er her det guddommelige forsyn (Agamben 2010: 172).

Den første af Agambens væsentlige opdagelser i Herskabet og herligheden er nu, at den 'regeringsmaskine', der udarbejdes i doktrinen om forsyn, har sit ophav i det græske begreb oikonomia (Agamben 2010: 67). Den kristne teologis udarbejdelse af den guddommelige forvaltning sker ikke med baggrund i en forestilling om en politisk stat, men derimod med baggrund i forestillingen om en husholdning - en økonomi (Agamben 2010: 87). For indeværende, hvor det i særdeleshed er forholdet mellem magt og sprog, som interesserer os, er det især én bestemt konsekvens af denne tanke, vi bør være opmærksomme på. Den kommer til udtryk i det andet af de to begreber, som udgør titlen på værket: herlighed. Hvorfor har magt nødvendigvis en forbindelse til herlighed (gloria) (Agamben 2010: 12)?

Agambens pointe er her, at herlighed ikke bare kan anses for at stå $i$ et instrumentelt forhold til magten. Den instrumentelle forklaring ville være den, der "i herligheden ser en strategi for de mægtige, til at retfærdiggøre deres ærgerrighed, eller en iscenesættelse af magten, som skal indgyde de underdanige med lydighed og ærefrygt" (Agamben 2010: 235). Det, som Agamben påpeger ved sin genealogiske undersøgelse, er, at den instrumentelle forklaring ikke stemmer overens med den meget tættere forbindelse mellem herskab og herlighed, som træder frem, når man følger hans pointe om, at oprindelsen til den moderne forståelse af forvaltningen 
af den politiske magt skal findes i den tidlige kristne teologis diskussion af forsynets 'økonomi' (Agamben 2010: 235). Agambens pointe er, at instrumentalismen opstiller et alt for ydre forhold mellem herskab og herlighed. Når herlighed forstås som et middel til at opretholde magten, så bliver den uvægerligt forstået som et andet for magten, som noget der ikke selv er magt, men som ved sin herlighed dog alligevel er bemægtigende.

Forestillingen om dette ydre forhold er problematisk af især to grunde. For det første viser Agambens undersøgelse, at forholdet mellem herskab og herlighed oprindeligt var langt mere indfiltret end instrumentalismen giver plads til. Eksempelvis påpeger Agamben, hvorledes triumftoget var helt afgørende for den juridiskpolitiske udvikling, der fandt sted med overgangen fra republik til kejsertid i Romerriget (Agamben 2010: 220). Triumfen var her ikke bare en fejring af magten, men derimod afgørende for hvorledes magten skiftede karakter og sted. Blandt andet blev kejserens ret til at bære våben under triumftoget afgørende - det var det eneste tidspunkt, hvor han havde ret til at bære dem i byen (Agamben 2010: 219-221). Påpegningen af, hvorledes forholdet mellem magt og herlighed fungerede i Romerriget, kan måske synes at være mindre relevant for, hvorledes forholdet fremtræder i dag, men Agambens pointe er nu, at disses strukturer er mere resistente, end vi almindeligvis forestiller os.

Den anden grund træeder tydeligt frem i et spørgsmål, som umiddelbart ikke virker mindre besynderligt end det, der overvejer hvor mange engle, der kan være på et knappenålshoved. I spørgsmål 108 opstiller Thomas Aquinas følgende problem: Hvad skal hærskarerne af engle lave efter den yderste dag? (Aquinas 1964: Q108, A7; Agamben 2010: 190). Dette er ikke noget simpelt problem. Hvor den økonomiske forståelse af forsyn tilsagde, at englene måtte være travlt beskæftigede med at arbejde for den guddommelige plan det vil sige med at frelse sjæle - så er det omvendt ganske svært at forestille sig, hvad englene skal lave efter den yderste dag, hvor dette arbejde må anses for at være tilendebragt. Thomas' svar er ganske klart: De skal synge guds lovprisning. Sagt på en anden måde, så er opgaven for englene, når de ikke har travlt med herskabet, at bevirke herlighed. Herligheden er det, som magten gør, når den ikke aktivt er i færd med at 'magte'. 
Netop fordi instrumentalismen tænker herlighed som et middel til at opretholde magt, og dermed stiller den som noget, der er eksternt til magten selv, så må den også tænke herligheden som noget, der indbefatter en bestemt form for aktivitet (som for eksempel bemægtigelsen). Herligheden tænkes dermed netop som noget, man gør, den er noget der aktivt opstilles, udøves og bevirkes. Det er imidlertid det samme som at sige, at herligheden selv er en form for magt; en form for aktiv handling. Instrumentelt set tænker man herlighed som noget, der gøres af nogen, for at noget andet skal ske. Herligheden tænkes dermed langt hen ad vejen som en bestemt form for talehandling, en aktivitet, som slet ikke er ulig den, vi ovenfor har beskrevet som sikkerhedsliggørelse. Men det, som den thomistiske undersøgelse af englenes funktion efter den yderste dag kan hjælpe os med at få blik for, er, at herligheden bør tænkes som noget helt andet - ja nærmest som det modsatte. Det vil sige: ikke som en (pseudo-magts) aktivitet uden for magten, som opretholder magten, men derimod som magtens egen inaktivitet. Herlighed er det som magten gør, når den ikke gør noget.

Det, som Agamben argumenterer for, ved at lægge vægt på disse noget skolastiske teologiske øvelser, er nu, at denne teologiske baggrund kan hjælpe os til at forstå den doxologiske side af magtens sprog, og i særdeleshed hjælpe os til at forstå vigtigheden af dette sprog. Akklamationer, lovprisninger, fejringer, som for den moderne instrumentalistiske forståelse af magt kan virke abstrakte og uvæsentlige, er snarere det stik modsatte. Hvad end det er den kristne kirkes 'Te Deum', eller 'Gloria', eller slet og ret 'Amen' (Agamben 2010: 276), eller om det er Nazi-Tysklands 'Heil Hitler' eller det fascistiske Italiens 'Duce Duce' (Agamben 2010: 302), så betegner disse forherligende sider af magtens sprog noget, som på en gang er af afgørende betydning for magten, men som samtidig netop ikke passer til modellen for sprog, som vi fandt $i$ både Schmitts analyse af barokkens juridiske regime, og i konstruktivistiske tilgange til magt som hos forskere som Wæver og Nandy; nemlig forestillingen om at sproget grundlæggende er kendetegnet ved, at nogen (mere eller mindre vellykket) aktivt gør noget. Det, vi finder hos Agamben, er derimod tanken om, at sprogets primære funktion er en bestemt form for inaktivitet.

I forhold til den pointe, jeg lavede ovenfor i de korte bemærkninger om Lacan, så kan vi nu også tydeligt se, hvor det er Agambens teori om forholdet mellem magt og sprog udmærker sig. Hvis instrumen- 
talismen indebærer en tilgang til dette forhold, hvor sproget altid ses som et middel, der aktivt kan benyttes til at nå et mål, så er Lacans indvending heroverfor, at vi aldrig kan være helt sikre på, at sproget 'når i mål', uanset om vi så benytter det i forbindelse med sikkerhedsliggørende talehandlinger, eller i forbindelse med mere juridisk bindende aftaler og traktater. ${ }^{2}$ Agamben derimod tilbyder nu en tredje variant, hvor det er selve forestillingen om sproget som primært værende en egentlig aktivitet, der udfordres. I det forherligende sprog finder han en bestemt sprogbrug, som ikke er en aktiv sætten af forskelle, men derimod en særlig form for inaktivitet. Eksempler på denne inaktivitet finder vi i de til tider næsten uendelige opremsninger af kongens, kejserens eller førerens dyder. Men vi finder den også i den moderne politiske virkelighed.

Her trækker Agamben igen på Schmitt. Ifølge Schmitt er det, som i daglig tale går under betegnelsen 'den offentlige mening' ikke andet end den moderne form for akklamation (Agamben 2010: 304). Igen og igen finder vi i offentlige debatter henvisninger til bestemte værdier, begreber eller normer, som ikke for alvor diskuteres, men som blot affirmeres - eller rettere akklameres. Det være sig fejringen af demokrati, menneskerettigheder eller ytringsfrihed, eller det være sig fordømmelsen af terrorisme. Ganske ofte har de offentlige meninger, der danner sig omkring disse begreber, ikke karakter af at være rationelle udvekslinger, men de har, således Agamben, lige så lidt karakter af at være egentlige sproglige konstruktioner eller talehandlinger, som definerer og sætter afgørende forskelle. I stedet har de netop karakter af at være steder, hvor sproget går i tomgang, holder op med aktivt at bevirke, og i stedet blot, ofte nærmest dovent, cirkulerer i en form for inaktivitet.

Der findes steder i magtens univers, hvor den, i stedet for at handle, blot er inaktiv og uproduktiv. Disse steder har ofte en noget anden karakter end det mere spektakulære, hvor magtens sprog sikkerhedsliggør, udpeger fjender og sætter efter dem. Det var netop denne mere spektakulære magtanvendelse, som vi så i de første år efter angrebene $9 / 11$. Her blev der startet krige og indført lovgivning, som af mange blev beskrevet som undtagelseslignende. Men efterhånden som terrorens trussel blev mindre og mindre præsent for den vestlige verdens opmærksomhed, så formindskedes også interessen for det problematiske ved den juridiske og politiske til- 
stand, som de umiddelbare reaktioner efterlod os med. I denne sammenhæng, efter et årti med ganske voldsomme omvendinger og kompromisser i forhold til basale juridiske rettigheder, så er det mest voldelige magten kan gøre, langt hen ad vejen ikke at gøre noget. Med andre ord så er det i dag snarere magtens inaktivitet end dens aktivitet, som bør interessere os, dersom vi ønsker at forholde os kritiske til det herskende juridisk-politiske regime.

\section{Konklusion}

Det er tid til at konkludere på de resultater, vi har nået i ovenstående. Vi har taget diskussionen om den nuværende juridisk-politiske situation op ud fra et teoretisk perspektiv, hvor det afgørende spørgsmål er, hvordan man bedst kan nærme sig de problemer, som vi står med i tiden efter 9/11. I denne forbindelse har vi berørt forskellige perspektiver, først og fremmest Schmitts og Agambens, som på den ene side kan siges at have en del til fælles, al den stund at Agambens teoretiske værk er dybt inspireret af Schmitt. På den anden side har dette fællesskab mellem Schmitt og Agamben af og til haft som sin konsekvens, at forskellene mellem de to magtteoretikere går tabt. Jeg har i det ovenstående forsøgt at vise, at man, hvis man overser forskellen mellem Agamben og Schmitt, risikerer at gå glip af en helt afgørende pointe, som er så meget desto mere væsentlig her 10 år efter 9/11.

Forskellen mellem de to tænkere udgøres af en indistinktionszone, som Agambens genealogiske undersøgelser har til formål at belyse. Denne zone kan virke som en underligt flygtig størrelse. I indeværende diskussion er den kommet til syne i en bestemt form for sprogbrug, som magten benytter sig af, ikke for at sikre og befæste sig selv, heller ikke for at dele verden op i venner og fjender, men derimod for at kunne vedblive med at være magt også, hvor den ikke er i færd med aktivt at "magte". Dermed når Agambens teori om suveræniteten frem til en anden pointe, end den som Schmitt åbner for. Når Schmitt følger Hobbes i forestillingen om, at hvor der ikke er en stærk og aktiv magt, som etablerer de spatiale og territoriale opdelinger, vi ifølge Schmitt har brug for, hvis vi skal kunne opretholde en funktionel retsorden, så har det alvorlige konsekvenser for hans muligheder for at tænke magtens tomrum. For Schmitt kommer magtens inaktivitet alt for let til at ligne anarki. Hvis den suveræne magt slækker på sin aktivitet, så skrider 
grænserne, og før vi får set os om, står vi i en mere eller mindre permanent borgerkrigslignende tilstand.

Men hvis vi følger Agamben, bliver det tydeligt, at magtens inaktivitet måske er det tætteste, vi kan komme på magtens kernebestemmelse. Hvis Agamben har ret i sin genealogiske analyse, så må det medgives, at magtens inaktivitet ikke bare kan sættes som en ekstern virkelighed udenfor magten selv. Den er derimod helt afgørende en del af magten selv. Den suveræne magts måske stærkeste kort er ikke der, hvor den spektakulært træffer beslutninger om undtagelsen, eller hvor den demonstrativt sætter sig igennem. Det er derimod der, hvor den er inaktiv. Lige netop på det sted, hvor Schmitt ser anarkiet vokse frem, kan vi med Agamben finde magtens kerne i en form for indistinktionszone. Eller som Agamben formulerer det med Pasolinis hjælp: "Det eneste sande anarki er magtens" (Agamben 2010: 84-5).

\section{Noter}

1 Citaterne i denne artikel er oversat af forfatteren.

2 Dette forhold ved sproget, at det måske i langt højere grad rammer ved siden af det intenderede mål, har jeg udforsket i flere detaljer i bogen The Metaphysics of Terror (Ugilt 2012).

\section{Litteratur}

Agamben, Giorgio (2004a): "Bodies Without Words: Against the Biopolitcal Tatoo" i German Law Review, vol. 5, nr. 2, s. 167-169.

Agamben, Giorgio (2004b [1995]): Homo sacer - sovereign power and bare life. Meridian, Stanford, Californien: Stanford University Press.

Agamben, Giorgio (2005 [2003]): State of exception, Chicago: Chicago University Press.

Agamben, Giorgio (2010 [2007]): Herrschaft und Herrlichkeit, Frankfurt am Main: Suhrkamp.

Aquinas, Thomas (1964): Summa Theologia, London and New York: Eyre and Spottiswoode, McGraw-Hill Book Company.

Buzan, B., Wæver, O., \& de Wilde, J. (1998): Security. A New Framework for Analysis, London: Rienner.

Lacan, Jaques (1998): Le séminaire, livre V, Formations de l'inconscient, Paris: Seuil. 
Lacan, Jaques (2002): Écrits, New York: W.W. Norton and Company.

Mattingly, G. (1963): «No Peace beyond What Line?» i Transactions of the Royal Historical Society, vol. 13, s. 145-162.

Nandy, Ashis (1995): “The Discreet Charms of Indian Terrorism" s. 1-31 i The Savage Freud and Other Essays on Possible and Retrievable Selves, Princeton, New Jersey: Princeton University Press.

Parker, M. (2009): "Angelic Organization: Hierarchy and the Tyranny of Heaven" i Organization Studies, vol. 30, nr. 11, side 1281-1299.

Schmitt, Carl (1974 [1950]): Der Nomos der Erde, Berlin: Duncker \& Humblot.

Schmitt, Carl (1985 [1922]): Political Theology, Chicago: University of Chicago Press.

Schmitt, Carl (2008 [1938]): The Leviathan in the State Theory of Thomas Hobbes, Chicago: University of Chicago Press.

Ugilt, Rasmus (2012): The Metaphysics of Terror, New York: Bloomsbury. 
